\title{
THE CHARACTERISTICS OF INSTRUCTIONAL SYSTEMATIC DESIGN ENGLISH ONLINE TEACHING ENVIRONMENT
}

\author{
Rizky Eka Prasetya
}

English Lecturer, Akademi Sekretari Budi Luhur, Jakarta

Corresponding Author Email: rizky.ekaprasetya@budiluhur.ac.id

\section{A B S T R A C T S}

The English online learning instructional model became contingent upon organised and guided learning practices by competent English lecturers as instructors in the online situation. There are a few concepts applied to the English instructional online pedagogy for Higher Education and Universities. The purposes of the examinations are to classify the relevance of online instructional learning to conform to English learning and present current or unexpected instructional design into the English online environment. The study employed a convergent parallel design method. This method of choice had depth-analysing and performing parallel analyses, which are considered alternative evidence for discussing the components of the online instructional model. The examination consisted of 52 English lecturers from various Higher Education and Universities. The survey questionnaires were addressed to participants, and interview strategies were identified to collect a distinctive angle and dept-involvement on the English online instructional. Findings of the study have revealed that English lecturers considered learner-centered intended course as very important for their teaching concept while emphasising real-world performance as important for the online environment material. Collaborative approach and concentrate on reliably and validly assessed outcomes become the second phase importance in the online instructional model. Interview protocols thematic analysis exposed that English lecturers should support and organise their particular English online instructional online environment. The general characterised adapted to engage in English online instructional online-based. The condition is because of English lecturers empathising with the appropriate material, approach to the learners' flexibility, and individual accomplishment in every topic.

\begin{tabular}{l}
\hline \multicolumn{1}{c}{ A R T I C L E I N F O } \\
\hline Article History: \\
Received: July, 2021
\end{tabular}

Revised: November, 2021

Published: December, 2021

Keywords:
Characteristics,
Instructional Systematic
Design,
English Online Learning,
Online Learning Environment,
Higher Education

Characteristics

Instructional Systematic

Online Learning Environment,

How to cite: Prasetya, R. (2021). The Characteristics of Instructional Systematic Design English Online Teaching Environment. Jo-ELT (Journal of English Language Teaching) Fakultas Pendidikan Bahasa \& Seni Prodi Pendidikan Bahasa Inggris IKIP, 8(2), 109-123. doi:https://doi.org/10.33394/jo-elt.v8i2.3994

\section{INTRODUCTION}

Indonesia was one of several nations experimenting with conducting online courses because of the covid 19 pandemics. In mid-March 2020, the education policymakers agreed to obtain a procedure to convert offline courses into online classes (Giatman et al., 2020). Digital or online sessions have been replacing the face-to-face Higher Education pedagogy process. The unexpected dilemmas brought to the emergence, ultimately. Fredericksen (2017) asserted that the online learning and teaching ecosystem were not permanently accepted as convenient as a conventional class. Every member of pedagogy is required to adapt and adjust to the unfamiliar environment. Conforming to the study, Margaryan et al. (2015) discovered a set of instructional' criteria focusing on learning materials and assistance to the 
first five to create a ten-principle scheme for classifying the instructional design quality of online courses. The cumulative knowledge, participation, diversity, authentic sources, and assessment were the other foundations. Larionova et al. (2018) supported that these principles inferred that learning was promoted when language learners contribute to cumulative knowledge; collaborate; make learning opportunities accommodated to their unprecedented requirements.

With imprecise teaching, ambiguous structure, and ineffective applications, English online learners' attention would eliminate from learning and onto technology, initiating further obstacles for instructors as English lecturers. (Brown and Green (2019) affirmed that instructional design (ID), alternatively referred to as systematic instructional design (ISD), signified developing instructional experiences that escalate the efficiency, effectiveness, and attractiveness of information and skill development. Linh and Suppasetseree (2016) added the identical English lecturers and learners benefit from an effective ISD procedure. An instructional design foundation functioned as a model for the structure and organisation of an online course ecosystem. Rafiq et al. (2019) asserted that it assisted learners in immediately concentrating on an English subject and eliminating distractions while empowering learners to take control of their learning style. Additionally, the mechanism supported English lecturers in preparing material and sequencing teaching.

Many English learning instructional design models have been generated in various educational contexts, taking English learning instructional design online models' primary purposes in mind (Wiphasith et al., 2016). Many models were available, ranging in complexity from basic to refined. Each of these resources included continuous instructions for creating English online learning guidance. Choe and Seong (2016) discovered that online instructional immersion was implemented in English Language Development (ELD) for learners living in countries where English was not the primary language. Ahmad et al. (2019) concluded that language immersion was suggested by the critical educational process that decorates English language learners with the knowledge to communicate efficiently and effectively in a social environment. Naturally, Cervantes-Soon et al. (2017) exposed that the aim was to devise boundless procedures that facilitate learners to receive required abilities faster and more thoroughly than would contrarily be challenged.

Nevertheless, English Language Development (ELD) was given by an English Second Language (ESL) instructor who either removes language learners from the regular classroom or enters to provide ELD help. While push-in/pull-out instruction could sometimes need close cooperation, paired ESL and classroom teachers regularly co-planning and co-instructing. According to Baecher and Bell (2017), these instances were the exception rather than the rule. In comparison, push-in was frequently lauded as a more "inclusive" model because instruction was ideally provided by two English lecturers collaborating within the mainstream classroom. While push-in was considered more collaborative and comprehensive than pullout, both models were constrained by the same limitations. Indeed, when Gibson (2016) compared ELD delivered as stand-alone teaching (pull out) to integrated education (push-in), they found ELLs made more considerable improvements in the pull-out approach since the instructor could concentrate solely on the English language proficiency.

The critical criteria of the English online course should also include its attractiveness and visibility, which may be achieved by offering instructional components in digital instruments as lists, outlines, and diverse visual objects. The most demanding role for course designers (English lecturers) was determining the communication between each exercise and the learning objectives and the activity and assessment methods deadlines. This step should 
include improving guidelines and instructions for activity production, preparing example assignments, and the system of mentor review schemes.

The English online instructional model had been recently investigated, explored, determined, and evaluated by Eristi \& Polat (2017), Tsai (2019), Chiang and Chen (2017), and Weiss et al. (2020). The general distinction point of view was still have been limited. The adaptation and change of English instructional in the conventional meeting would perceive challenging for the Higher Education level, and it is because the English learners' goals and expectations are implied to the English practical in the workplace. Therefore, finding a general outcome was necessary to improve English pedagogy in the online environment. The research study involved 1) How are the priorities of instructional English online courses in Higher Education?; 2) How can English lecturers comprehend instructional English online courses to their virtual class?.

\section{RESEARCH METHOD}

The study addressed utilising the convergent parallel design. The data was gathered into two types of qualitative and quantitative methods. The online Likert-scale survey accomplished the quantitative descriptive design, and the distribution was supported to google form based on the online platform. Moreover, The Semi-Structured In-depth interviews were deliberately applied to collect data for qualitative case-study design, and it was organised by conference call.

\section{Research Design}

A convergent parallel design mixed-method design signified that the research functioned both quantitative and qualitative aspects simultaneously at the same period of the research process, fairly weights both techniques, analyses both individually, and describes the findings accordingly. The study was divided into two types of research designs. Descriptive research is a quantitative study that gathers measurable data on a population sample to conduct statistical analysis. It is a universally practised educational research instrument that implements the collection and characterisation of demographic phenomena in educational environments. Nonetheless, A qualitative content analysis technique was employed to assess the interview data acquired. The transcribed replies of the participants completed the initial step, and it was carefully examined to determine the vital data units depending on the goal of the research. The units were designated through the notions review of relevant literature or the participants' language. These classifications helped reveal the themes underpinning the participants' opinions, attitudes, and backgrounds. Parallel case studies served as a tool for establishing how a concept or idea may be referred to in educational settings.

\section{Subject}

The mixed-method study necessitated implementing quantitative and qualitative design methods. The cluster sample design was employed for 46 respondents in the quantitative viewpoint. Meanwhile, the same number of participants were involved in purposive sampling from the qualitative perspective. The English lecturers were the subject of the study, and they were from several Higher Education and Universities in South Jakarta. The detailed information is shown in table 1. 
Table 1

Demographic Participants Details

\begin{tabular}{cccc}
\hline \multicolumn{2}{c}{ Attribute } & Frequency & Total in \% \\
\hline \multirow{2}{*}{ Gender } & Female & 37 & $68 \%$ \\
\cline { 2 - 4 } & Male & 17 & $32 \%$ \\
\cline { 2 - 4 } & $1-5$ years & 5 & $9 \%$ \\
\cline { 2 - 4 } Years of Lecturer's & $5-10$ years & 17 & $31 \%$ \\
\cline { 2 - 4 } Experience & $10-15$ years & 16 & $29 \%$ \\
\cline { 2 - 4 } & $15-20$ years & 12 & $22 \%$ \\
\cline { 2 - 4 } & 20 years & 9 & $16 \%$ \\
Education Levels & Master's & 41 & $75 \%$ \\
\cline { 2 - 4 } & Doctoral & 13 & $15 \%$ \\
\hline The Familiarity of & High & 8 & $15 \%$ \\
Online Pedagogy & Moderate & 19 & $35 \%$ \\
Environment & Low & 27 & $50 \%$ \\
\cline { 2 - 4 } & &
\end{tabular}

\section{Instruments}

The study conducted an online survey and interview to collect authentic information from English lecturers' experience and their English online instructional design that they have completed for one year in organising English online educational circumstances. The principal instruments Likert-scale survey of study adapted to the instructional model contributed to the instructional concept of ADDIE (analyse, design, develop, implement, and evaluate) developed by Ghani and Daud (2018). Bloom Taxonomy (knowledge, comprehension, application, analysis, synthesis, and evaluation) was accustomed to Armstrong (2017). Nevertheless, the depth semi-structured interview accommodated Flipped Classroom (peer instruction, team-based learning, problem-based learning, inquiry-based learning, and case-based learning) developed by Zuber (2016). The survey has the support of delivering large quantities of in-depth data rather expeditiously. Interviews were adopted to gather data from respondents or participants about views, expectations, and feelings about conditions in their concepts. Depth semi-structured interviews provide insight into participants' mindsets, the significance of events for the respondents or participants involved, material about the location, and perhaps information on unanticipated issues, and it provided immediate follow-up and clarification of participants' responses.

\section{Data Analysis}

The study was indicated into two types, concentrated the qualitative and quantitative data interpretation. Distribution descriptive statistics have accommodated the study, and it interested the Likert Scale frequency of value very important, important, not important, and not sure. This aspect accomplished central tendency measures utilised to establish the middle, or typical, data collection. The mean, median, and mode were three methods for measuring the average. However, depth interview was referred thematic data analysis. It applied to conduct the qualitative views by gathering information about English lecturers' attitudes, beliefs, knowledge, experiences, and values from several qualitative data. This inductive thematic analysis approach involved facilitating the information or data to determine the study's themes. Table 2 was the information detail of mean interpretation of the study. 
Table 2

Mean Interpretation Guide

\begin{tabular}{ccc}
\hline Scale & Mean Range & Interpretation \\
\hline 4 & $3.50-4.00$ & Very Important \\
\hline 3 & $2.50-3.49$ & Important \\
\hline 2 & $1.50-2.49$ & Not Important \\
\hline 1 & $1.00-1.49$ & Not Sure \\
\hline
\end{tabular}

\section{RESEARCH FINDINGS AND DISCUSSION Research Findings}

The participants' responses Likert-Scale survey was organised in the research instrument. The character of online instructional learning has been categorised based on finding into six stages: involve learner-centred design, establish design aims to clear objectives, emphasises real-world performance, and concentrate on reliably and validly assessed outcomes, design based on empirical evidence, and collaborative approach. On the other hand, the dept semi-structured interviews were employed to gain a better perspective and genuine understanding of participants. This part covered the findings of the survey and in-depth interviews. The study exposed convergent parallel design mixed method emphasised the presentable quantitative statistical results and then provided qualitative quotes to support the statistical results. All the experiences and perspectives had mentioned in the survey and interview were evaluated as very important, important, and not important by participants' points of view. It could be inferred that all the outlooks listed in the instruments were fundamental, particularly in implementing an English online learning environment. However, the measures of central tendency are promoted by each item and examined more thoroughly. The parameters gave a more evident recognition of which explanations were considered significant value.

\section{Involve Learner-Centered Design}

Table 3

The Responses Finding Involve Learner-Centred Design

\begin{tabular}{|c|c|c|c|c|}
\hline \multirow{2}{*}{ No } & \multirow{2}{*}{ Learner-Centred Instructional Design (A) } & \multicolumn{3}{|c|}{$\begin{array}{l}\text { How Important the Instructional } \\
\text { is in the Online Course }\end{array}$} \\
\hline & & Mean & SD & $\begin{array}{c}\text { The Importance } \\
\text { Level }\end{array}$ \\
\hline 1. & $\begin{array}{l}\text { English lecturer investigates meaning, so the classroom must } \\
\text { offer chances for participation, engagement, and socialising. }\end{array}$ & 4.00 & 0.00 & Very Important \\
\hline 2. & $\begin{array}{l}\text { Students should be exposed to new knowledge and ideas } \\
\text { regularly. }\end{array}$ & 3.89 & 0.33 & Very Important \\
\hline 3. & $\begin{array}{l}\text { English lecturers and learners establish friendly environment } \\
\text { encounters as a means of self-discovery }\end{array}$ & 3.67 & 0.50 & Very Important \\
\hline 4. & $\begin{array}{l}\text { Learners should participate in collaborative problem-solving } \\
\text { activities that apply to real-world situations. }\end{array}$ & 3.15 & 0.84 & Important \\
\hline 5. & The teacher must consider how students learn. & 2.79 & 1.24 & Not Important \\
\hline 6. & $\begin{array}{l}\text { Language learners have actively involved and driven In an online } \\
\text { classroom environment, }\end{array}$ & 4.00 & 0.00 & Very Important \\
\hline 7. & $\begin{array}{l}\text { English lecturers offer technology-based activities that aid in } \\
\text { learners' motivation and the development of critical thinking } \\
\text { skills. }\end{array}$ & 3.65 & 0.47 & Very Important \\
\hline 8. & $\begin{array}{l}\text { English lecturers employ multimedia software, and students may } \\
\text { create sound files, which can help in communication between the } \\
\text { educators and learners }\end{array}$ & 3.45 & 0.69 & Important \\
\hline 9. & $\begin{array}{l}\text { English lecturers facilitate courses that incorporate various } \\
\text { aspects of the language learners' life would enhance student } \\
\text { engagement and foster productive learning settings. }\end{array}$ & 4.00 & 0.00 & Very Important \\
\hline 10. & $\begin{array}{l}\text { The online learning process should give language learners } \\
\text { responsibility, which may help them feel more responsible for } \\
\text { their online learning. }\end{array}$ & 3.08 & 0.61 & Important \\
\hline
\end{tabular}


Table 3 presented an overall view of the importance of based on the learners' centred design. The highest mean (4.00) includes A.1 and A.9. This indications proof that interaction became vital in the online learning environment. The important aspect (3.08 - 3.45) involved A4, A8, and A.10. Several English lecturers affirmed that the condition, approach, and feature would affect these interactions among English lecturers and learners or vice versa. Based on the participants' responses, these ten indicators referred to the highest importance for their English online instruction ecosystem, except the approach to knowing and understanding how language learners understand the material (A.5). These learner-centred indications prove that online learning maintains to swift teacher-oriented (centred) to be learners' perspective. The online course dynamic should be used when students actively engage while the instructor seems to be taking an (apparently) passive role. It all observed to group work, one-on-one tutoring between students and the instructor in the online classroom. Language learners ought to take an active role. No educators could tell learners how to create something and expect them to do it after leaving the online classroom.

"Our teaching approach and style had transformed since online pedagogy began. It did not reflect the Indonesian habitually concentrated on English educators' standpoint. Online learning utilised a unique environment in internet-based communication to be different from the conventional class. Learners centred must be done to have effective English online pedagogy." (Rep. 09)

Although the English educators or instructors did not offer the necessary tools, language learners frequently completed their online learning studies. They created experience through practising the student-centred method by assembling, interpreting knowledge, and combining it with customary capacities. Communication became critical thinking and problem-solving. In a student-centred approach, learners were involved in determining a learning method. As a result, not only the instructor but also the students must choose the best learning method. Learners negotiated with the English lecturers on the essential learning choices. Learner-centred instruction involves Language learners in the complex and challenging process of learning. However, English lecturers ought to give them a chance to improve their main capabilities in English practical knowledge. The purposes were encouraged and activated their motivation to learn by personal learning style. The interaction must be dominant in this stage, and the primary goal was to give a better perspective on the English lecturers' view related to the language learners' achievement.

\section{Establish Design Aims to Clear Objectives}

Table 4

The Responses Finding Establish Design Aims to Clear Objectives

\begin{tabular}{|c|c|c|c|c|}
\hline \multirow{2}{*}{ No } & \multirow{2}{*}{ Establish Design Aims to Clear Objectives (B) } & \multicolumn{3}{|c|}{$\begin{array}{l}\text { How Important the Instructional is } \\
\text { in the Online Course }\end{array}$} \\
\hline & & Mean & Mean & $\begin{array}{l}\text { The Importance } \\
\text { Level }\end{array}$ \\
\hline 1. & $\begin{array}{l}\text { The online learning fundamental core process is that } \\
\text { components in the teaching-learning process are set goals. }\end{array}$ & 2.56 & 1.13 & Important \\
\hline 2. & $\begin{array}{l}\text { Prerequisite is planned and implemented to the degree of } \\
\text { knowledge and abilities students must possess before } \\
\text { moving on to more advanced topics. }\end{array}$ & 3.67 & 0.50 & Very Important \\
\hline 3. & $\begin{array}{l}\text { A diagnostic exam, often known as a pretest, is used to } \\
\text { determine the learners' preparedness. }\end{array}$ & 3.44 & 1.01 & Important \\
\hline 4. & $\begin{array}{l}\text { A diagnostic exam is used to evaluate how well a student } \\
\text { understands the course or teaching. }\end{array}$ & 3.11 & 0.93 & Important \\
\hline 5. & $\begin{array}{l}\text { The evaluation determines the language learners' degree of } \\
\text { mastery of the material. }\end{array}$ & 3.73 & 0.24 & Very Important \\
\hline 6. & $\begin{array}{l}\text { The learning process is based on deciding whether to go on } \\
\text { to the next subject, reteach the language learners, or } \\
\text { provide tutorials. }\end{array}$ & 3.62 & 0.32 & Very Important \\
\hline
\end{tabular}




\begin{tabular}{clccc}
\hline 8. & $\begin{array}{l}\text { English lecturers assisted in the form of scaffolding based } \\
\text { on the interaction activity. }\end{array}$ & 3.54 & 0.61 & Very Important \\
\hline 9. & $\begin{array}{l}\text { English lecturers use precise teaching delivery methods } \\
\text { and styles. }\end{array}$ & 3.52 & 0.31 & Very Important \\
\hline 10. & $\begin{array}{l}\text { English lecturers use flexibility grouping in the online } \\
\text { class in synchronous and asynchronous meetings. }\end{array}$ & 3.31 & 0.45 & Important \\
\hline 11. & $\begin{array}{l}\text { English lecturers advocate for attracting methods that } \\
\text { engage active language learners' virtual participation. }\end{array}$ & 3.17 & 0.84 & Important \\
\hline 12. & $\begin{array}{l}\text { English lecturers use assistive and proper educational } \\
\text { technology. }\end{array}$ & 2.87 & 1.32 & Not Important \\
\hline 13. & $\begin{array}{l}\text { English lecturers provide intensive guidance in every } \\
\text { online session. }\end{array}$ & 2.62 & 1.07 & Important \\
\hline
\end{tabular}

The responses to the perspective instructional design should be clearly shown in table 4. The fundamental importance established to the varied important and very important involved the score mean for $3.15-3.73$ and related to most of the statements in the table. The highest mean (3.73) selected B.5, and the lowest mean (2.56) acknowledged B.1. All these parameters referred to the supplementary approach and style for implementing an English online environment. The five-statement (B.2; B.5; B.6; B.8; and B.9) related to the very important six statements (B.1; B.3; B.4; B.10; B.11; and B.13) concerned with the necessary background, and one statement (B.12) reflected the not important. From this point of view, giving the goals and objectives became crucial in the online learning environment. English language proficiency is concerned with the conception, design, administration, and measurement of systems for teaching and learning. The instructional design offered technology that helps in the goal-oriented and forward-thinking design of teaching and learning in various learning settings

"We cannot generate the unclear objectives in both mechanism online and offline classroom. Learners gained a better intrinsic motivation to know what they learn and how they can achieve it. As English lecturers and instructors, we needed to recognise their personal ability to have a precise improvement in the online environment." (Rep. 01)

Learning goals assisted instructors in selecting and organising course material and determining the kinds of assessments and learning activities to include in a course. The creation of instructional methods and learning activities might guide learning goals. Learning goals should ideally outline a path for the student to gain new skills, information, and attitudes. Every choice English lecturers make regarding their lecture, or small group session should be based on what every pedagogy member can accomplish. A few minutes before English lecturers finished the session, materials and practices to ascertain those goals were valuable in creating effective learning environments for English lecturers and professional growth.

\section{Emphasises Real-World Performance}

Table 5

Responses Finding Emphasises Real-World Performance

\begin{tabular}{|c|c|c|c|c|}
\hline \multirow{2}{*}{ No } & \multirow{2}{*}{ Emphasis on Real-World Performance (C) } & \multicolumn{3}{|c|}{$\begin{array}{l}\text { How Important the Instructional is } \\
\text { in the Online Course }\end{array}$} \\
\hline & & Mean & Mean & $\begin{array}{c}\text { The Importance } \\
\text { Level }\end{array}$ \\
\hline 1. & $\begin{array}{l}\text { The material offers for native speakers in a particular } \\
\text { objectives' practical skill. }\end{array}$ & 3.46 & 0.27 & Important \\
\hline 2. & $\begin{array}{l}\text { The material provides the various genuine speakers/writers } \\
\text { with an actual point to communicate for a real audience. }\end{array}$ & 3.21 & 0.36 & Important \\
\hline 3. & $\begin{array}{l}\text { The material can be accessed to the online environment so } \\
\text { that language learners can self-review }\end{array}$ & 3.47 & 0.48 & Important \\
\hline
\end{tabular}




\begin{tabular}{|c|c|c|c|c|}
\hline 4. & $\begin{array}{l}\text { English lecturers and learners have to communicate } \\
\text { personally or collectively related to their learning } \\
\text { problems. }\end{array}$ & 2.50 & 0.28 & Important \\
\hline 5. & Language learners can select the online material available. & 3.64 & 0.37 & Very Important \\
\hline 6. & $\begin{array}{l}\text { English lecturers create online course classrooms with } \\
\text { assessment testing to become supplementary. }\end{array}$ & 3.57 & 0.64 & Very Important \\
\hline 7. & $\begin{array}{l}\text { The online material reflects the language learners' cultural } \\
\text { environment }\end{array}$ & 3.17 & 0.57 & Important \\
\hline 8. & $\begin{array}{l}\text { The online material refers to the goal interaction in an } \\
\text { online environment applied with video conference or } \\
\text { instant messaging }\end{array}$ & 3.91 & 0.38 & Very Important \\
\hline 9. & $\begin{array}{l}\text { The online material aspect includes employment, } \\
\text { technology, consumer goods, consumer-related services, } \\
\text { and citizenship and civic participation }\end{array}$ & 3.34 & 0.77 & Important \\
\hline 10. & $\begin{array}{l}\text { Reading is supported by periodicals, books, articles, } \\
\text { product labels, and other such office-related materials. }\end{array}$ & 3.64 & 0.12 & Important \\
\hline 11. & $\begin{array}{l}\text { Listening to the casual conversation and recordings, radio, } \\
\text { and other media }\end{array}$ & 3.42 & 0.29 & Important \\
\hline 12. & $\begin{array}{l}\text { the material offer observing support complementary } \\
\text { English films or networks on video multimedia. }\end{array}$ & 3.57 & 0.37 & Very Important \\
\hline 13. & $\begin{array}{l}\text { English lecturers establish an environment where the } \\
\text { English language is spoken utilising multimedia in the } \\
\text { online ecosystem. }\end{array}$ & 3.71 & 0.47 & Very Important \\
\hline 14 & The material provides slang language. & 3.26 & 0.64 & Important \\
\hline
\end{tabular}

Table 5 showed indications that actual or authentic material is needed in the online environment. The primary goal is to create a close-related context and establish the language's original setting culturally. Eight selected important items and six very important had represented the participants' experience. The highest mean included the C.1 for 3.46 very important, yet the lowest mean was C.4 for 2.50. Statement C.5; C.6; C.8; C.12 and C.13 would determine the learners' English proficiency, the ideal material to choose, and the course topic the instructor wants to emphasise. The standard deviation was acceptable because the standard deviation value reflected the objective, and score enhancement SD could vary. SD implied the positive value, equal to or higher than 0 . The materials should represent situations that learners may face in an English-speaking context since this will help them adjust to life in a world where English is the standard. Authentic resources should assist students in overcoming emotions of loss and other unfavourable connections with learning processes. When feasible, simple language should be utilised in education, according to one of the critical principles of communicative language teaching. The condition referred to the C.5, C.8, C.10, and C.14. Developments in the online learning language were recognised in the resources, allowing language learners and lecturers to remain current. Keep language learners timely on current developments globally to have an integrated educational and technological value.

"Online learning has given us (English lecturers) a chance to get authentic or real material from the online ecosystem. We could add more listening practices from news, advertising company, etcetera. Despite that, English lecturers gave them material enrichment related to their communication future capabilities needs. That is the goals of English for Specific Purposes" (Rep. 20)

In the language and culture classroom, online technologies could represent natural resources directly applicable to students. English lecturers may use natural resources to foster communication based on the delivery and response of important knowledge. They facilitate learners to communicate in the language they are learning, principally outside of the classroom, when they are unlikely to comprehend every word said or written. When genuine materials are used, people have a more favourable view of the target culture. Because technology is a technique and enables students to engage with materials according to their 
learning style rather than having a learning style imposed by the instructor's design of the course materials, online sources may accommodate individual learning styles. As a result, technology enables students to have more influence over their classroom atmosphere.

\section{Concentrates on Reliably and Validly Assessed Outcomes}

Table 6

Responses Finding Concentrates on Reliably and Validly Assessed Outcomes

\begin{tabular}{|c|c|c|c|c|}
\hline \multirow[b]{2}{*}{ No } & \multirow{2}{*}{$\begin{array}{c}\text { Concentrates on Reliably And Validly Assessed } \\
\text { Outcomes (D) }\end{array}$} & \multicolumn{3}{|c|}{$\begin{array}{l}\text { How Important the Instructional is } \\
\text { in the Online Course }\end{array}$} \\
\hline & & Mean & Mean & $\begin{array}{l}\text { The } \\
\text { Importance } \\
\text { Level }\end{array}$ \\
\hline 1. & $\begin{array}{l}\text { Language learners' interaction behaviours are the } \\
\text { quantifiable and qualitative components. }\end{array}$ & 4.00 & 0.00 & $\begin{array}{c}\text { Very } \\
\text { Important }\end{array}$ \\
\hline 2. & $\begin{array}{l}\text { English lecturers have references to the appropriate } \\
\text { methods of the online assessment. }\end{array}$ & 2.75 & 1.42 & Important \\
\hline 3. & $\begin{array}{l}\text { The quantifiable element entails Specific student } \\
\text { performance criteria/success criteria. }\end{array}$ & 3.67 & 0.51 & $\begin{array}{c}\text { Very } \\
\text { Important }\end{array}$ \\
\hline 5. & $\begin{array}{l}\text { The online assessment is concise, brief, and } \\
\text { understandable to language learners. }\end{array}$ & 3.25 & 0.39 & Important \\
\hline 6. & $\begin{array}{l}\text { The learning process becomes vital information to the } \\
\text { assessment techniques. }\end{array}$ & 3.81 & 0.58 & $\begin{array}{c}\text { Very } \\
\text { Important }\end{array}$ \\
\hline 7. & Performance practical is the online learning outcome & 3.64 & 0.76 & $\begin{array}{l}\text { Very } \\
\text { Important }\end{array}$ \\
\hline 8. & $\begin{array}{l}\text { The online observation was used as a technique of } \\
\text { evaluation. }\end{array}$ & 3.51 & 0.81 & $\begin{array}{l}\text { Very } \\
\text { Important }\end{array}$ \\
\hline 9. & $\begin{array}{l}\text { The online survey can be supplementary proficiency to the } \\
\text { subject }\end{array}$ & 3.35 & 0.89 & $\begin{array}{c}\text { Very } \\
\text { Important }\end{array}$ \\
\hline 10. & $\begin{array}{l}\text { English lecturers and learners can access the evaluation } \\
\text { book with the detailed transcription goal and outcome }\end{array}$ & 4.00 & 0.00 & $\begin{array}{l}\text { Very } \\
\text { Important }\end{array}$ \\
\hline 11. & $\begin{array}{l}\text { The examining demographic language learners can have } \\
\text { individual evaluation and participation in the online } \\
\text { environment }\end{array}$ & 3.81 & 0.91 & $\begin{array}{l}\text { Very } \\
\text { Important }\end{array}$ \\
\hline 13. & $\begin{array}{l}\text { Focus group establish more context to have evaluation and } \\
\text { assessment of the online environment. }\end{array}$ & 3.25 & 1.29 & Important \\
\hline 14 & GPA is not the primary score & 4.00 & 0.00 & $\begin{array}{c}\text { Very } \\
\text { Important }\end{array}$ \\
\hline
\end{tabular}

Table 6 discovered the participants' experience and expectations in their online teaching course. D.1, D.10, and D.14 were the highest mean with a 4.00 score and described as very important. The statement related to the rational and comprehensible structure would support improving learning results and, as a result, student achievement in the online course. Language learners create plans for expected learning, outcomes, assignment dates, rubrics, and rules for assignments to improve student learning and excellent results. The range of 3.50 - 3.85 was related to D.6, D.11, D.3, D.7, and D.8. The statement had parameter the observed student learning result was an excellent predictor of student happiness, and learning outcomes positively impact the academic achievement. The importance level involved the D.5, D.13, and D. 2 with a mean range of $2.75-3.25$. All the indicators related to the Language learners' learning expectations have a beneficial impact on the student experience in online courses throughout the epidemic. As indicated in the figure, all factors had a substantial indirect impact on English online learning achievement performance.

"It was essential for the measurement and evaluation to be accessible in an online setting. English instructors were challenged to offer relevant education experiences at a distance, regardless of whether they utilised synchronous or asynchronous online sessions, as the education sector engaged with the effect of Covid-19. It was critical to 
monitor students' well-being and their entire distance learning experience and monitor academic progress. Simple inquiries might elicit students' responses." (Rep. 31)

English lecturers or instructors were especially challenged in online learning, where there was no face-to-face (F2F) contact to properly communicate their goals and give relevant feedback to assist students to accomplish the intended learning objectives. "The remote character of Web-based methods complicated many observational and participatory evaluations." Because of the lack of face-to-face interaction, informal evaluation may be particularly challenging for online teachers. A greater understanding of the assessment difficulties and successful methods of online instructors might aid in creating a framework for researching and practising online teaching.

\section{Design Based on Empirical Evidence}

Table 7

Responses Finding Design Based on Empirical Evidence

\begin{tabular}{|c|c|c|c|c|}
\hline \multirow[b]{2}{*}{ No } & \multirow[b]{2}{*}{ Design Based on Empirical Evidence (E) } & \multicolumn{3}{|c|}{$\begin{array}{l}\text { How Often the Instructional is in the } \\
\text { Online Course }\end{array}$} \\
\hline & & Mean & Mean & $\begin{array}{c}\text { The } \\
\text { Importance } \\
\text { Level }\end{array}$ \\
\hline 1. & $\begin{array}{l}\text { English lecturers engage learners to participate in a virtual } \\
\text { meeting by asking questions. }\end{array}$ & 3.16 & 0.23 & Important \\
\hline 2. & $\begin{array}{l}\text { Students should recognise when they need more } \\
\text { knowledge and work to enhance their learning idea. }\end{array}$ & 3.46 & 0.67 & $\begin{array}{c}\text { Very } \\
\text { Important }\end{array}$ \\
\hline 3. & $\begin{array}{l}\text { Students should concentrate on heuristics to complete } \\
\text { necessary assignments. }\end{array}$ & 3.51 & 0.41 & $\begin{array}{l}\text { Very } \\
\text { Important }\end{array}$ \\
\hline 4. & $\begin{array}{l}\text { Lecturer of English uses rubrics, handouts, and exercises } \\
\text { as the framework. }\end{array}$ & 3.67 & 0.67 & $\begin{array}{l}\text { Very } \\
\text { Important }\end{array}$ \\
\hline 5. & An English lecturer applies flexible time. & 4.00 & 0.00 & $\begin{array}{c}\text { Very } \\
\text { Important }\end{array}$ \\
\hline 6. & $\begin{array}{l}\text { English lecturers use reflections of process assessment and } \\
\text { self-reflection. }\end{array}$ & 3.45 & 0.79 & Important \\
\hline 7. & $\begin{array}{l}\text { English lecturers generate discussion to the learners related } \\
\text { their challenges and acceptance to the topic's objective. }\end{array}$ & 3.62 & 0.55 & $\begin{array}{c}\text { Very } \\
\text { Important }\end{array}$ \\
\hline 9. & $\begin{array}{l}\text { English lecturers use formative feedback on mid-term } \\
\text { deliverables such as fundamental future concepts. }\end{array}$ & 3.45 & 0.39 & Important \\
\hline 10. & $\begin{array}{l}\text { English lecturers use an online survey to clarify ideas } \\
\text { before the next online course. }\end{array}$ & 3.77 & 0.47 & $\begin{array}{c}\text { Very } \\
\text { Important }\end{array}$ \\
\hline
\end{tabular}

Table 7 showed the finding revealed that important includes to E.1, E.6, and E.9 with range mean score 3.16 - 3.45. It showed that the primary feature of conventional instructional models is that they solve institutional issues using a generic problem-solving approach that includes feasibility study and definition and planning, implementing, and delivering a product. The statement E.2, E.3, E.7, E.4, E.10, and E.5 perceived the mean range score for $3.46-4.00$. The standard deviation ranged from $0.00-0.79$, indicating how much variability there is in a particular data collection. It represented how far specific data points in a data collection vary from their intended meaning. The finding was a continuation of the preceding tables' results. Participants' corresponding preceded all the abilities given as "important" or "very important." They considered nothing not important. Additionally, the finding emphasised the meanings derived from each item, and one may determine which abilities are deemed essential. It was deserving of perceiving those techniques were considered identical for both accommodating English online courses.

"Our faculty has designed the current lesson plan and syllabus for the curriculum. It referred to the various aspect of object and subject. The online learning was 
implemented unexpectedly, but our team has prepared the practical method to accommodate the English online learning environment." (Rep. 29)

Designing instructional was related to empirical investigations that describe what occurs through direct observation, focus group discussions, and in-depth interviews. These include case reports and small-scale research studies with a small sample size that do not show statistical relationships between variables. These data were needed by the instructional designer to have correlated to the new impact or authenticity language learners need. Higher education English learning levels must avoid the unclear goals to every content. It aimed to have efficient and effective English online learning.

\section{Generate Collaborative Approach}

Table 8

Responses Finding Generate collaborative approach

\begin{tabular}{|c|c|c|c|c|}
\hline \multirow{2}{*}{ No } & \multirow{2}{*}{ Generate Collaborative Approach (F) } & \multicolumn{3}{|c|}{$\begin{array}{l}\text { How Often the Instructional is in } \\
\text { Online Course }\end{array}$} \\
\hline & & Mean & Mean & $\begin{array}{l}\text { The Importance } \\
\text { Level }\end{array}$ \\
\hline 1. & $\begin{array}{l}\text { Language learners should participate actively in the } \\
\text { learning process. }\end{array}$ & 3.48 & 0.86 & Important \\
\hline 2. & $\begin{array}{l}\text { Language learners' activities are related to reading, } \\
\text { talking, and writing in the online instrument environment. }\end{array}$ & 3.81 & 0.46 & Very Important \\
\hline 3. & $\begin{array}{l}\text { English lecturers concentrate on learners' abilities rather } \\
\text { than delivering knowledge. }\end{array}$ & 4.00 & 0.00 & Very Important \\
\hline 4. & $\begin{array}{l}\text { English lecturers increase the observation of attitudes and } \\
\text { values in language learners. }\end{array}$ & 3.53 & 0.47 & Very Important \\
\hline 5. & $\begin{array}{l}\text { English lecturers provide engagement material to motivate } \\
\text { language learners in the online environment }\end{array}$ & 3.46 & 0.82 & Important \\
\hline 6. & $\begin{array}{l}\text { Students should get direct online direct feedback on their } \\
\text { achievement. }\end{array}$ & 3.97 & 0.79 & Very Important \\
\hline 7. & $\begin{array}{l}\text { Students should be placed on relatively high thinking } \\
\text { capabilities. }\end{array}$ & 4.00 & 0.00 & Very Important \\
\hline 9. & $\begin{array}{l}\text { English lecturers offer a cooperative online environment } \\
\text { with access to monitor }\end{array}$ & 3.24 & 0.42 & Important \\
\hline 10. & English lecturers and learners encourage to interact more & 3.64 & 0.47 & Very Important \\
\hline 11. & $\begin{array}{l}\text { English lecturers promote critical thinking among learners } \\
\text { and aids in the clarity of concepts. }\end{array}$ & 3.19 & 0.76 & Important \\
\hline 12. & $\begin{array}{l}\text { English lecturers promote the acceptance of individual } \\
\text { diversity of learners. }\end{array}$ & 4.00 & 0.00 & Very Important \\
\hline
\end{tabular}

The discovery of the collaborative learning aspect has been shown in table 8 . The statement had been an ideal representative of collaborative online learning. Primary data selected were mainly to the very important, and it had a range mean score for $3.53-4.00$ with F.4, F.10, F.2, F.6, F.3, F.7, and F12. Meanwhile, the important level involved the 3.19 - 3.48 with E.1, E.11, E.9, and E.5. The mean score finding exposed higher than standard deviation score, which meant the statement variation ideally distribution. The finding might maintain that the scores in the data were tightly scattered around the mean since the standard deviation value was around 0.5 . The coefficient of variance may be computed, and a remark was distributed if the mean value is possible. Furthermore, the collaborative learning practice allowed group members to know a subject or process they could not accomplish independently. Language learners might collaborate in person, inside or outside of the online class, or utilise technology to facilitate group discussions or complete collaborative writing assignments in an online environment.

"English lecturers or course designers should have planned to conduct online learning to concentrate on the interaction between English lecturers and learners. They need to maintain the learners' motivation in the isolated place. Online learning 
emphasises independent learning so that the outcome would be different for every learner." (Rep. 37)

Language learners could employ collaborative learning in an online context, and learning activities might be designed to facilitate the development of a learning community. These practices possibly ranged from discussion boards to small group exercises. While online contact and collaboration benefits had long been acknowledged, the instructional design of course objectives and activities encouraging perpetual learners' engagement and participation for comprehension building remains unexplored. Online learning should facilitate more focused and engaging engagement, and investigation must verify both the mental mechanisms and the outcomes.

\section{Discussion}

Changing the English online learning course to a learner-centred approach does not mean sacrificing English content or high standards. In this environment, students are more engaged; they are asking, evaluating, considering, qualifying, and creating conclusions. English lecturers' role as instructors or online learning course creators shifts the attitude to foster a robust learner-centred environment. English course designers should develop the mindset and establish purposes that explain the language learners' necessities to achieve their objectives following the online course. Designing online learning could be varying the language learners' potential harmony to a solid approach to increase learned accountability. Language learners were involved in generating their meaning and learning rather than waiting for information to be presented.

English Online learning environments must be constructed following the positive knowledge about language pedagogy instructional construct paradigms, and the English instructor required their students to have a minimum level of capability to complete the appointed tasks. Zheng et al. (2020) determined that learning goals, also known as performance objectives or instructional objectives, convey what language learners would achieve after a season of teaching and learning. Learning goals were related to online courses and frequently indicated in the same pattern. The students will accomplish this after the training is clear. Self-assessment or independent assessment, one of three online mechanisms students may engage in, is seen as a critical component of the evaluation process. It is defined as a reasonable period when English learners can evaluate their performance on a particular assignment. They should be able to assess their degree of competence. The goal must be clear in order for pupils to be successful in their learning. Language learners might mark the relationship between what they are doing in class and what they need to know.

The more efficient English lecturers' instructional online pedagogy planning, the vaster the expectation they would achieve. Hwang (2018) stated that planning online instruction or activities means establishing language learners' preferences, objectives, and objectives. English lecturers' lesson plans vary extensively, revealing the English lecturers' experience, grade achievement, and preparation courses. Planning was more than understanding what English teaching intended to accomplish. Instructors or English lecturers think about the details, such as who does what, when, for what range of time, and what opportunities will be established for effective English online learning. Calamlam et al. (2021) asserted that the primary intention of the online instructional design procedure was to provide that all activities and processes maintain a supportive online educational environment for the language learner.

Identifying and developing online instructional objectives had consideration takes time and planning. An authentic content or material was a very important element in English online learning and instruction in a real-life scheme and served the community's social intention. There are three components for selecting authentic texts: content appropriateness, exploitability, and intelligibility. Cundell \& Sheepy (2018)) established that language learners have trouble studying English online due to inadequate instructional resources. Language 
learners must be motivated to gain new proficiency. As a result, instructional materials must engage and stimulate the attention of language learners. They would learn nothing if instructional materials were not engaged and uplifting.

English lecturers were mainly concerned with English online class instructional methods because they believed their situation was to educate and that language learners need some teaching. English lecturers selected suitable material, developed instructional methods, determined appropriate instruments, delivered teaching, and assessed student learning. As a result, instructors or English lecturers were required to determine available resources for adapting to evolving circumstances rather than using the traditional classroom method. Vanoostveen et al. (2019) affirmed that the resource selection process is centred on the English lecturers' requirement to find, acquire, modify, or augment current educational materials. Another characteristic of online classroom-oriented instructional design approaches is their choice rather than creating online educational resources.

\section{CONCLUSION}

An English online instructional designer creates learning experiences. However, the situation is a bit more complex than that. The origins of instructional design may be traced back to behavioural psychology. It aims to comprehend the behaviours that result in the most effective learning results. Instructional designers offer a methodical approach to the creation of learning experiences. Instructional designers have compassionate hearts. They put themselves in the shoes of their learners and create educational experiences for them. Every learning experience has a particular audience, of which instructional designers are aware. As a result, the better the learning results, the more customised the experience is to that audience. If English lecturers or instructional designers ignored the learners' requirements, interests, and abilities, the overall online learning outcomes would be lost.

Instructional design was a consultative process. all the related students could not start designing a successful English online learning experience until they first engaged with key stakeholders to understand their English online requirements. They must traverse connections quickly to be a successful instructional designer and be engaged. Language learners offer value whenever feasible. Instructional designers were well-known for their methodical approach to English online learning design, so they must also apply the same mentality to their task. It is impossible to overestimate the value of data in any learning intervention. Without this information, instructional designers have been unaware. They will not know if the experience they produced was successful or not. Once they have access to the data, they must analyse it and derive valuable insights. This condition enabled instructional designers to update their learning experiences successfully. Following that, they may gather more datasets and repeat them until they have got it exactly perfect.

Instructional designers brought a methodological approach to learning design. Effective online instruction regularly required corralling information from a variety of different sources. English lecturers or instructors need to handle all this detail in their minds and communicate it effectively. It is important to remember that inaccuracies can have an actual online process and educational impact. English online materials must be visually engaging if they are to be effective. There is no more agile way to fall a language learners' interest than to present them with a wall of text. As such, instructional design often goes together with graphic design.

\section{REFERENCES}

Ahmad, M. K., Adnan, A. H. M., Azamri, N. M., Idris, K. B., Norafand, N. N., \& Ishak, N. I. (2019). Education 4.0 technologies for English language teaching and learning in the Malaysian context. Proceedings of the International Invention, Innovative \& Creative (InIIC) Conference, Series, 6-16.

Armstrong, P. (2017). Bloom's Taxonomy. Vanderbilt University Center for Teaching. 
Baecher, L., \& Bell, A. B. (2017). Opportunity to teach: Push-in and pull-out models of English learner instruction. Journal of Education and Culture Studies, 1(1), 53-68.

Brown, A. H., \& Green, T. D. (2019). The essentials of instructional design: Connecting fundamental principles with process and practice. Routledge.

Calamlam, J. M., Ferran, F., \& Macabali, L. G. (2021). Perception on research methods course's online environment and self-regulated learning during the COVID-19 pandemic. E-Learning and Digital Media, 20427530211027720.

Cervantes-Soon, C. G., Dorner, L., Palmer, D., Heiman, D., Schwerdtfeger, R., \& Choi, J. (2017). Combating inequalities in two-way language immersion programs: Toward critical consciousness in bilingual education spaces. Review of Research in Education, 41(1), 403-427.

Chiang, F.-K., \& Chen, C. (2017). Modified flipped classroom instructional model in "learning sciences" course for graduate students. The Asia-Pacific Education Researcher, 26(1-2), 1-10.

Choe, E., \& Seong, M.-H. (2016). A Case Study of the Flipped Classroom in a Korean University General English Course. Journal of Pan-Pacific Association of Applied Linguistics, 20(2), 71-93.

Cundell, A., \& Sheepy, E. (2018). Student perceptions of the most effective and engaging online learning activities in a blended graduate seminar. Online Learning, 22(3), 87102.

Eristi, B., \& Polat, M. (2017). The Effectiveness of Synectics Instructional Model on Foreign Language Vocabulary Teaching. Online Submission, 5(2), 59-76.

Fredericksen, E. E. (2017). A national study of online learning leaders in US higher education. Online Learning, 21(2), n2.

Ghani, M. T. A., \& Daud, W. (2018). Adaptation of ADDIE instructional model in developing educational website for language learning. Global Journal Al-Thaqafah, $8(2), 7-16$.

Giatman, M., Siswati, S., \& Basri, I. Y. (2020). Online learning quality control in the pandemic Covid-19 era in Indonesia. Journal of Nonformal Education, 6(2), 168-175.

Gibson, C. (2016). Bridging English Language Learner Achievement Gaps through Effective Vocabulary Development Strategies. English Language Teaching, 9(9), 134-138.

Hwang, A. (2018). Online and hybrid learning. Journal of Management Education, 42(4), 557-563.

Larionova, V., Brown, K., Bystrova, T., \& Sinitsyn, E. (2018). Russian perspectives of online learning technologies in higher education: An empirical study of a MOOC. Research in Comparative and International Education, 13(1), 70-91.

Linh, N. D., \& Suppasetseree, S. (2016). The Development of an Instructional Design Model on Facebook Based Collaborative Learning to Enhance EFL Students' Writing Skills. IAFOR Journal of Language Learning, 2(1), 48-66.

Margaryan, A., Bianco, M., \& Littlejohn, A. (2015). Instructional quality of massive open online courses (MOOCs). Computers \& Education, 80, 77-83.

Rafiq, K. R. M., Hashim, H., Yunus, M. M., \& Pazilah, F. N. (2019). Developing a MOOC for communicative english: A battle of instructional designs. International Journal of Innovation, Creativity and Change, 7(7), 29-39.

Tsai, Y.-R. (2019). Promotion of learner autonomy within the framework of a flipped EFL instructional model: Perception and perspectives. Computer Assisted Language Learning, 1-32.

Vanoostveen, R., Desjardins, F., \& Bullock, S. (2019). Professional development learning environments (PDLEs) embedded in a collaborative online learning environment (COLE): Moving towards a new conception of online professional learning. Education and Information Technologies, 24(2), 1863-1900. 
Weiss, M. P., Glaser, H., \& Lloyd, J. W. (2020). An Exploratory Study of an Instructional Model for Co-Teaching. Exceptionality, 1-14.

Wiphasith, H., Narumol, R., \& Sumalee, C. (2016). The design of the contents of an elearning for teaching M. 5 English language using ADDIE model. International Journal of Information and Education Technology, 6(2), 127.

Zheng, B., Ward, A., \& Stanulis, R. (2020). Self-regulated learning in a competency-based and flipped learning environment: learning strategies across achievement levels and years. Medical Education Online, 25(1), 1686949.

Zuber, W. J. (2016). The flipped classroom, a review of the literature. Industrial and Commercial Training. 